\title{
An Empirical Study on the Relationship Between Foreign Investors and Earnings Quality
}

\author{
Yohan $\mathrm{An}^{1}$ \\ ${ }^{1}$ Department of Finance \& Accounting, College of Business Administration, Tongmyoung University, Republic of \\ Korea
}

Correspondence: Yohan An, Department of Finance \& Accounting, College of Business Administration, Tongmyoung University, Republic of Korea.

Received: August 12, 2019

Accepted: September 18, 2019 Online Published: September 28, 2019

doi:10.5430/rwe.v10n3p99

URL: https://doi.org/10.5430/rwe.v10n3p99

\begin{abstract}
This study examines the impact of foreign investors on earnings quality in emerging capital market using Korean manufacturing firms' panel data set, regarding competing for international investment and business opportunities during the period 2000 to 2012. This paper tests earnings quality using four proxies based on the International Financial Reporting Standards: 1) persistence, 2) value relevance, 3) conservatism, and 4) accruals quality. This research finds foreign investor is positively associated with only user needs earnings quality; persistence and value relevance. This result shows that the positive impact of foreign investor on earnings quality is evident but limited.
\end{abstract}

Keywords: foreign investors, foreign directors, earnings quality, panel data

\section{Introduction}

In emerging capital market, rapid increasing of foreign direct investment (FDI) makes foreign investor as a major institutional investor to play a key corporate governance role. Many previous studies on the relationship between foreign investor and corporate governance in emerging countries support the significant benefits from foreign participation against tunneling of controlling shareholders or family ownership (Aggarwal et al., 2011, Min and Bowman, 2015). This study investigates the impact of foreign investor on earnings quality of Korean firms listed on the Korean Stock Exchange (KSE) during the sample period from 2000 to 2012 having motivation on importance of foreign investors in Korean capital market. The Korean data has an outstanding condition for testing the corporate governance role of foreign investor on earnings quality as a measure of financial reporting quality. First, Korea has been ranked one of the highest foreign direct investment countries in the world. For example, as of 2013, foreign investors in the KSE reached by 35 per cent. Foreign investors demand improvements in financial reporting quality of Korean firms with increased sharehold of foreign investment so that the Korean data provides a good environment for testing the impact of foreign investor on financial reporting quality caused by foreign direct investment. Second, much attention has been given to the impact of foreign investor on firm value not financial reporting quality. After math of the Asian Financial Crisis in 1997, Korean government removes limitation of foreign investor to improve financial reporting quality using their knowledge and skill on corporate governance and management. Since most firms in Korea has controlling or family shareholders, corporate governance mechanism has not properly been worked due to dominance of controlling family shareholders. Firms with large foreign investor expect to improve firm's financial reporting quality because of foreign investors's professional management knowledge and corporate governance practices.

This study expects to contribute the literature on the relationship between foreign investor and financial reporting quality in several ways. First, the role of foreign investors as outside monitors of corporate governance activities, is gradually increasing bigger specifically in most emerging countries because of higher foreign investors shareholdings. In spite of the importance of foreign investor in emerging countries, there are very limited empirical studies of the relationship between foreign investor and earnings quality. This study examines to find whether foreign investors contribute to improve financial reporting quality. In addition, this study provides important evidence that how foreing investor's participation in the board of directors affects earnings quality. Thus, results of this study might shed light on the relationship between foreign investors and earnings quality not only for the Korean context but also for other emerging countries. Finanlly, this study extends prior research by comprehensively exploring the 
effects of foreign investors on four measures of earnings quality: persistence, value-relevance, conservatism, and accruals quality.

\section{Literature Review \& Hypothesis Development}

\subsection{Earnings Quality}

Earnings quality, as a measure of financial reporting quality, is the most primary measure provided in financial statements (Lev 1989) and the most comprehensive measure for financial reporting quality (Balsam et al. 2003). In this study, earnings quality as a proxy of financial reporting quality can be assessed by two types of different approaches: user needs and shareholder/investor protection following Jonas and Blanchet (2000). In the view of user needs, the purpose of financial statements should provide useful information to users in making economic decision, thereby making a difference to their decisions. Schipper and Vincent (2003) propose that earnings persistence and value-relevance are derived from a decision usefulness perspective. Under the category of shareholder/investor protection, financial information should not mislead or confuse financial information users and should be fully and fairly disclosed because information asymmetry occurs between management and financial information users. Ball et al. (2000 and 2003) assert that conservatism captures financial statement transparency. Schipper and Vincent (2003) suggest that accruals quality is consistent with the representational faithfulness perspective. In the context of shareholder/investor protection, earnings quality can be measured by conservatism and accruals quality.

\subsection{Foreign Investor}

As a large institutional investor, there are two conflicting view on the foreign investor: active monitoring and transient hypothesis. According to the active monitoring hypothesis, foreign investors play an important role in monitoring management to protect their interests (Sachs and Warner 1995) and to resolve their information asymmetry (Kang and Stulz 1997). He and Shen (2014) investigates the impact of foreign investors on the informational efficiency of share price in Japan firms and find increase in foreign investor improves share price efficiency. In emerging market study, foreign institutional investors in China significantly reduce expropriation by controlling shareholders because foreign investors are less related to political pressure and positively monitor invested firms (Huang and Zhu 2015). After the removal of foreign investor limitation in Taiwan, foreign investors contribute significant growth to Taiwan capital market and increase voluntarily disclosure of Taiwan firms (Lien, Tseng, and $\mathrm{Wu} 2013$ ). Thus, foreign investors seem to play a valuable monitoring role as a large institutional investor. External monitoring by foreign investors as a large institutional investors can constrain the opportunities for discretionary choices of management in providing financial accounting information, thereby increasing earnings quality.

However, in the view of transient hypothesis, foreign investors are just short-term investors and thus they do not have significant incentives to monitor firm's management (Graves 1988; Kim, Krinsky, and Lee 1997). Grinblatt and Keloharju (2000) report that domestic investors are less sophisticated and take the opposite position to that of more sophisticated foreign investors in the Finnish market. They interpret that foreign investors tend to pursue momentum strategy but domestic investors seem to be contrarian. Dahlquist and Robertsson (2001) argue that the extent of the deviation for foreign investors from holding the market portfolio is mostly similar to institutional investors. They find that foreign portfolio investors underinvest in firms with a dominant owner and more invest large firms, firms paying low dividend, and firms with large cash position on their balance sheet in the Swedish market. Choe, Kho, and Stulz (2005) find that foreign investors in Korea are more likely to be momentum investors than domestic investors. This result implies that foreign investors are sophisticated investors but transient institutional investors.

\subsection{Testable Hypotheses}

In Korea, the potentially positive impact of foreign investors can be understood as a special application of the more general proposition that large outside blockholders can mitigate family managerial opportunism because foreign investors in Korean firms are less likely to be related to controlling shareholders. In addition, foreign investors have a higher burden of monitoring costs due to greater information asymmetry (Kang and Stulz 1997; Choe et al. 2005). Foreign investors will therefore positively strengthen their monitoring function to resolve information asymmetry. in Korea, active monitoring hypothesis is more fit to foreign investor as large institutional shareholders rather than transient hypothesis. Choi et al. (2011) document that foreign block investors have a preference for firms with enhanced management accountability and take into account in selecting shares for their block investment whether a firm has strong corporate governance practice. In particular, the board seat of foreign directors is one of the major conditions for investment by foreign investment firms. Oxelheim and Randøy (2003) find that firms with foreign outside directors (Anglo-American) have a higher valuation in the Scandinavian markets since appointment of 
foreign outside directors (Anglo-American) provides positive signal for firms with capital market. Accordingly, foreign outside directors can increase earnings quality through participation in internal governance mechanism.

To the extent that external monitoring by foreign investors is intense and effective, the opportunities for discretionary choices in providing accounting information become more constrained. In order to protect their wealth and to reduce monitoring costs, foreign investors have stronger incentives and expertise to independently monitor firms. Thus, higher proportions of foreign investor induce firms to improve transparency and to decrease opportunistic managerial accounting choices and decisions. Based on these arguments, the following hypotheses for the association between foreign investor and earnings quality are tested:

Hypothesis One: Foreign investor is positively associated to earnings quality in Korean firms.

Hypothesis Two: Foreign director is positively associated to earnings quality in Korean firms.

\section{Research Methodology}

\subsection{Sample Selection}

This study uses Korean firms listed on the Korean Stock Exchange (KSE) for 13 years (2000-2012). All financial institutions (e.g., commercial banks, insurance firms, security brokerage firms) are excluded because accounting methods and the format of financial statements differ to other industries and are subject to different regulatory requirements. Financial statements data and stock data are obtained from OSIRIS and KIS-VALUE database respectively. Ownership data are all manually collected from business reports of each firm on DART system (http://dart.fss.or.kr) provided by the Korean Financial Supervisory Commission (KFSC) the equivalent to the SEC in Korea. The final sample consists of panel data of 489 non-financial Korean firms and a total of 6,357 firm-year observation over the 13 year periods. The sample firms belong to 10 industry groups based on the Korean Standard Industry Classification (SIC).

\subsection{Measure of Earnings Quality}

Earnings quality as a proxy of financial reporting quality is classified into two categories: 1) user needs and 2) shareholder/investor protection. In the view of user needs, earnings quality is measured as persistence and value-relevance, while earnings quality under the shareholder/investor protection is measured as conservatism and accruals quality. To address the association between earnings quality and foreign investors, earnings quality is set as a dependent variable following Francis, LaFond, Olsson, and Schipper (2004) methodology.

As earnings quality proxy of user needs, this study measures earnings persistence as the slope-coefficient $\left(\beta_{1}\right)$ estimates of regression of current earnings on previous earnings Earnings persistence means how much of current earnings will persist into the future and continue from period to period. In order to measure the value-relevance of accounting information, this study uses Francis et al. (2004) methodology that price as a function of both earnings and book value of equity. The explanatory power of regression $\left(R^{2}\right)$ is used as the metric to measure the value-relevance of earnings and book value. As earnings quality proxy of shareholder/investor protection, This study measures conservatism using Ball and Shivakumar's (2005) accruals-based test of loss recognition model. Conservatism is measured by the incremental coefficient on the association between accruals and negative cash flows. Accruals quality is measured following Dechow and Dichev (2002). Accruals quality for each firm is measured as the absolute value of firm-level residuals $\left(\left|\varepsilon_{i, t}\right|\right)$ from industry level pooled cross-sectional regression of total current accruals on lagged current, and future cash flows plus the change in revenue and gross property, plant, and equipment.

\subsection{Measure of Foreign Investor and Foreign Director}

Foreign investor $(F O R E I G N)$ is percentage of equity shares held by all foreign investors as of the end of the year, and calculated as the total number of shares held by foreign investors divided by the total number of shares outstanding. Foreign directors (FORBOD) is a dummy variable that indicates the presence (one) or absence (zero) of registered foreign citizens on the board.

\subsection{Control Variables}

The following five variables that may affect earnings quality are included to control for potential influences on earnings quality: 1) firm size (SIZE), 2) leverage $(L E V), 3)$ firm with negative earnings (LOSS), 4) growth prospects $(G R W)$, and 5) profitability $(R O A)$.

\subsection{Empirical Model}

The following regression equation is formulated to examine the relationship between foreign investors and earnings quality 


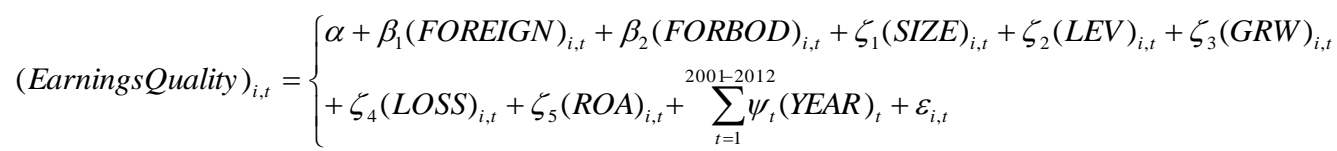

The primary estimation method of the regression will be pooled-OLS following Francis et al. (2004). Due to the advantage of panel data set (cross-sectional time-series), there are more reliabilities to estimate regression. The robustness check will be employed with Generalized Least Square (GLS) random-effects estimation.

\section{Empirical Results}

\subsection{Descriptive Statistics}

Table 1 shows the descriptive statistics for variables. As for earnings quality on the user needs, the mean (median) of persistence in the sample is 0.314 (0.263), and the mean (median) of value-relevance is $0.453(0.452)$. Turning to earnings quality on shareholder/investor protection, conservatism has a mean (median) value of 0.193 (0.079), and accruals quality has a mean (median) value of $0.108(0.017)$, respectively. Foreign investor $(F O R E I G N)$ has the mean value of 0.108 and the median value is 0.017 . The severe difference between mean and median of foreign investor implies that foreign investor is concentrated in specific firms. This feature of foreign investor supports that foreign investors prefer large manufacturing firms with good accounting performance, lower unsystematic risk, and lower leverage but underweight smaller and highly leveraged firms (Kang and Stulz 1997).

The large industry groups of foreign investor in this sample are chemical \& rubber plastic (64 per cent) and electronics \& electric manufacture (39 per cent) while the smalls are construction (4.8 per cent) and textile \& footwear (6.9 per cent). This feature of foreign investor supports that foreign investors prefer large manufacturing firms with good accounting performance, lower unsystematic risk, and lower leverage but underweight smaller and highly leveraged firms (Kang and Stulz 1997, Choi et al. 2007). The mean value of outside directors who are foreigners $(F O R B O D)$ is 0.052 . Namely, approximately 5 per cent of Korean firms appoints foreigner as outside directors on board.

Table 1. Description of the samples

\begin{tabular}{|c|c|c|c|c|c|c|}
\hline Categories & Variables & Mean & Median & Min & $\operatorname{Max}$ & $\begin{array}{l}\text { Standard } \\
\text { Deviation }\end{array}$ \\
\hline \multirow{2}{*}{$\begin{array}{c}\text { Earnings Quality } \\
\text { (User Needs) }\end{array}$} & PERSISTENCE & 0.314 & 0.263 & -4.634 & 11.188 & 0.703 \\
\hline & VALUE RELEVANCE & 0.453 & 0.452 & 0.003 & 0.992 & 0.253 \\
\hline \multirow{2}{*}{$\begin{array}{c}\text { Earnings Quality } \\
\text { (Shareholder/Investor } \\
\text { Protection) }\end{array}$} & CONSERVATISM & 0.193 & 0.079 & -77.72 & 54.415 & 6.436 \\
\hline & $\begin{array}{c}A C C R U A L S \\
Q U A L I T Y\end{array}$ & 0.076 & 0.023 & $1.48 \mathrm{E}-05$ & 3.362 & 0.199 \\
\hline \multirow{2}{*}{$\begin{array}{c}\text { Independent Variabls } \\
\text { (Foreign Investors) }\end{array}$} & FOREIGN & 0.108 & 0.017 & 0.000 & 0.982 & 0.145 \\
\hline & FORBOD & 0.052 & 0.000 & 0.000 & 1.000 & 0.216 \\
\hline \multirow{5}{*}{ Control Variables } & SIZE & 21.230 & 19.430 & 12.922 & 25.890 & 1.456 \\
\hline & $L E V$ & 0.546 & 0.495 & 0.017 & 27.478 & 0.729 \\
\hline & LOSS & 0.229 & 0.000 & 0.000 & 1.000 & 0.412 \\
\hline & $G R W$ & 1.268 & 0.387 & 0.0002 & 288.00 & 6.912 \\
\hline & $R O A$ & 0.014 & 0.036 & -4.724 & 3.599 & 0.231 \\
\hline
\end{tabular}

\subsection{Empirical Results}

Table 2 presents on the results of pooled-OLS estimates of the association between earnings quality in the view of user needs (e.g., persistence and value-relevance) and in the view of shareholder/investor protection (e.g., conservatism and accruals quality) and foreign investors variables, respectively.

Foreign investor (FOREIGN) is significantly positive with earnings quality on user needs. The coefficient estimates of FOREIGN on persistence are 0.478 at the 0.01 level. The relation between value-relevance and FOREIGN also has strong positive coefficient (0.193) at the 0.01 level. In the association with earnings quality on shareholder/investor protection, no positive impact between FOREIGN and both on conservatism and accruals 
quality. FOREIGN is not statistically significant for conservatism while the coefficient of FOREIGN (0.081) is strongly significant for accruals quality at 0.01 level. The positive impact of foreign investor on earnings quality supports only user needs earnings quality; persistence and value-relevance. Foreign investor does not provide evidence of a positive association with earnings quality on shareholder/investor protection. Thus, the positive effect of foreign investor on earnings quality requires more detailed interpretation. Both conservatism and accruals quality reflect a firm's potential accounting earnings change by management, while earnings persistence and value-relevance can be used to explain firm value. Accordingly, no positive impact of FOREIGN on earnings quality in the view of shareholder/investor protection implies that foreign investors may be less likely to actively monitor due to a lack of substantial information on firm's management. However, the strong positive relationship between foreign investor and earnings quality on user needs might reflect foreign investors' investment preference for financially stable firms. As shown in Table 1, the severe difference between mean and median of foreign investor can indirectly support this result. Thus, the positive impact of foreign investor on earnings quality should be limitedly accepted and carefully interpreted.

Foreign outside directors $($ FORBOD) is negatively related to persistence $(-0.227)$ and value-relevance $(-0.025)$ at 0.01 level and 0.10 level, respectively. Foreign outside directors are expected to have independence and competency, thereby increasing earnings quality. Inconsistent with this expectation, foreign outside directors is negatively related to persistence and value relevance. In the association with earnings quality on shareholder/investor protection, FORBOD shows conflicting results. The coefficients of FORBOD on both conservatism and accruals quality are $1.078(p<0.05)$ and $0.103(p<0.01)$, respectively. Namely, foreign outside directors increase conservative accounting practice but decrease accruals quality. This conflicting result can be explained by two ways. First, foreign outside directors do not have much knowledge and information on the firm and its internal information. In addition, foreign outside directors is less likely to actively participate board meeting. For example, the Coporate Governence Service (CGS) in Korea reports that the attendance ratio of foreign outside directors on board meetings in Korean firms is 49.3 per cent as of 2007 which is below average ( 72 per cent). Therefore, foreign outside directors have a limited monitor influence on a firm's management. Second, foreign investors prefer financially stable firms, thus foreign outside directors also prefer conservative accounting practice to avoid investment risk. Accordingly $\mathrm{H}_{2}$ is only applied to conservatism.

Several control variables represent significant relation with earnings quality. Firm size (SIZE) is significantly positive with value-relevance $(0.037)$ at 0.10 level. In the association with conservatism and accruals quality, SIZE is negatively related to conservatism $(-0.193)$ at 0.05 level and has positive values $(0.070)$ with accruals quality at 0.01 level. This means that earnings of large firms have more value-relevence, while their earnings are more inflated or managed by management discretion due to their political power and organizational complexity (Watts and Zimmerman 1990). Leverage ( $L E V)$ is positively related to persistence $(0.031)$ at 0.10 . The positive association between $L E V$ and persistence suggest that firms with high leverage are actively operated (Ross 1977), and debt holders of firms positively affect firm's earnings by monitoring firm's management (Choi et al. 2007). Negative earnings (LOSS) is positively related to both value-relevance $(0.028)$ and accruals quality $(0.042)$ at 0.05 level and 0.01 level, respectively. The positive association between value-relevance and LOSS suggests that stock price more significantly respond to negative earnings. Negative earnings increases estimated errors of accruals, thereby decreasing firm's accruals quality. The positive value of the coefficient of LOSS on accruals is consistent with this expectation. The coefficients of a firm's accounting profitability $(R O A)$ on persistence and value-relevance have positive values $(0.114$ and 0.039$)$ at 0.10 level. This association shows that high accounting profitability increases persistence 
Table 2. Pooled-OLS results

$$
(\text { EarningsQuality })_{i, t}=\left\{\begin{array}{l}
\alpha+\beta_{1}(\text { FOREIGN })_{i, t}+\beta_{2}(\text { FORBOD })_{i, t}+\zeta_{1}(\text { SIZE })_{i, t}+\zeta_{2}(L E V)_{i, t}+\zeta_{3}(G R W)_{i, t} \\
+\zeta_{4}(\text { LOSS })_{i, t}+\zeta_{5}(R O A)_{i, t}+\sum_{t=1}^{2001-2012} \psi_{t}(Y E A R)_{t}+\varepsilon_{i, t}
\end{array}\right.
$$

Subscripts $i$ denotes individual firms, $t$ time period. The dependent variable Earnings Quality is four measures of earnings quality: 1) Persistence, 2) Value-Relevance, 3) Conservatism, and 4) Accruals Quality. FOREIGN is the percentage of equity shares held by foreign investors. Foreigner $(F O R)$ is a dummy variable that indicates the presence (one) or absence (zero) of registered foreign citizens on the board.. Firm size $(S I Z E)$ is the natural log of the total assets. Leverage ( $L E V)$ is total debt scaled by total assets. Growth prospects $(G R W)$ is market to book ratio of equity. Firm with negative earnings $(L O S S)$ is a dummy variable that takes the value of one if firm's pervious year's net income was negative, and zero otherwise. Profitability $(R O A)$ is return on assets. YEAR is a time dummy.

Superscripts *, **, and $* * *$ indicate statistical significance at $10 \%, 5 \%$, and $1 \%$ levels, respectively. $(t$-statistics $)$

\begin{tabular}{|c|c|c|c|c|c|}
\hline & & \multicolumn{2}{|c|}{ User Needs } & \multicolumn{2}{|c|}{ Shareholde/Investor Protection } \\
\hline \multicolumn{2}{|c|}{ Variables } & Persistence & $\begin{array}{c}\text { Value-Relevanc } \\
\mathrm{e}\end{array}$ & Conservatism & Accruals Quality \\
\hline Independe & FOREIGN & $\begin{array}{c}0.478 * * * \\
(4.469)\end{array}$ & $\begin{array}{c}0.193 * * * \\
(4.952)\end{array}$ & $\begin{array}{c}0.541 \\
(0.543)\end{array}$ & $\begin{array}{l}0.081 * * \\
(2.394)\end{array}$ \\
\hline nt Variabls & FORBOD & $\begin{array}{c}-0.227 * * * \\
(-3.588)\end{array}$ & $\begin{array}{l}-0.025^{*} \\
(-1.991)\end{array}$ & $\begin{array}{l}1.078 * * \\
(2.208)\end{array}$ & $\begin{array}{c}0.103 * * * \\
(4.742)\end{array}$ \\
\hline \multirow{5}{*}{$\begin{array}{l}\text { Control } \\
\text { Variables }\end{array}$} & SIZE & $\begin{array}{c}0.008 \\
(0.082) \\
\end{array}$ & $\begin{array}{l}0.037 * \\
(1.475)\end{array}$ & $\begin{array}{c}-0.193 * * \\
(-2.096)\end{array}$ & $\begin{array}{c}0.070 * * * \\
(20.289) \\
\end{array}$ \\
\hline & LEV & $\begin{array}{l}0.031 * \\
(1.648)\end{array}$ & $\begin{array}{c}0.006 \\
(0.949) \\
\end{array}$ & $\begin{array}{c}-0.214 \\
(-1.226) \\
\end{array}$ & $\begin{array}{l}0.011 * \\
(1.813) \\
\end{array}$ \\
\hline & GRW & $\begin{array}{c}-0.011 \\
(-0.392)\end{array}$ & $\begin{array}{c}-0.010 \\
(-0.965)\end{array}$ & $\begin{array}{c}0.269 \\
(1.064)\end{array}$ & $\begin{array}{c}-0.028 * * \\
(-1.978) \\
\end{array}$ \\
\hline & LOSS & $\begin{array}{l}-0.075 * * \\
(-2.167) \\
\end{array}$ & $\begin{array}{l}0.028 * * \\
(2.223)\end{array}$ & $\begin{array}{l}-0.353 * * \\
(-2.091) \\
\end{array}$ & $\begin{array}{c}0.042 * * * \\
(3.477) \\
\end{array}$ \\
\hline & ROA & $\begin{array}{l}0.114 * \\
(1.680) \\
\end{array}$ & $\begin{array}{l}0.039 * \\
(1.956) \\
\end{array}$ & $\begin{array}{c}-0.271 \\
(-0.410) \\
\end{array}$ & $\begin{array}{c}-0.032 \\
(-1.188) \\
\end{array}$ \\
\hline \multicolumn{2}{|c|}{ Constant } & $\begin{array}{l}0.391 * * \\
(2.044)\end{array}$ & $\begin{array}{c}0.433 * * * \\
(6.185)\end{array}$ & $\begin{array}{l}3.978 * * \\
(2.232)\end{array}$ & $\begin{array}{l}-1.312 * * * \\
(-19.912) \\
\end{array}$ \\
\hline Model Fits & $\begin{array}{c}A d j \mathrm{R}^{2} \\
F-\text { Statistics }\end{array}$ & $\begin{array}{c}0.021 * * * \\
5.274 \\
\end{array}$ & $\begin{array}{c}0.038 * * * \\
9.981\end{array}$ & $\begin{array}{c}0.014 * * \\
3.083\end{array}$ & $\begin{array}{c}0.214 * * * \\
100.371 \\
\end{array}$ \\
\hline
\end{tabular}

As this study utilizes panel data, panel study methodology should be considered. According to Himmelberg et al. (1999), the choice of ownership structure depends on unobserved firm characteristics such as contractual, regulatory, or informational environment. With panel data, one common treatment of this unobserved time-constant effect is to use fixed-effect (FE) regression, known as least square dummy variable (LSDV) analysis (Wooldridge 2002; Baltagi 2005). Himmelberg et al. (1999) suggest that firm fixed effects estimators should be used in examination of the relationship between ownership and firm performance because the cross-sectional variation in ownership explained by unobserved firm heterogeneity is a firm fixed effect. However, Zhou (2001) argues that the firm fixed effect model in panel data is not appropriate in this setting because ownership typically changes slowly from year to year within a firm. Namely, the ownership-firm value relationship is likely to be a cross-sectional phenomenon.

Extending Zhou's (2001) argument, FE estimation is not suitable for this thesis for three reasons. First of all, FE estimation requires significant within panel (firm) variations of the variable values to produce consistent and efficient estimates. The inclusion of firm fixed effects essentially removes most cross-sectional variations of the dependent variable, thus the effect of other explanatory variables (e.g., SIZE, GRW etc.) may not be observed unless ownership and board composition measures exhibit substantial time-series variations. Thus, the FE estimates would be imprecise. Second, FE estimates may aggravate the problem of multicollinearity due to using so many dummies known as LSDV (Baltagi 2005 p.13). Third, when panel data set (observations on 489 firms over 13 years in this study) consists of large ' $N$ ' (489 firms) and fixed small ' $T$ ' (13 years), FE estimation is inconsistent (Baltagi 2005, p.13). Moreover, for large $N$, FE estimation would lead to an enormous loss of degrees of freedom (Baltagi 2005, 
p.14). Fourth, when the sample was extracted from a large population (listed firms on the KSE in this study), individual specific constant terms regarded as randomly distributed across cross-sectional firms (Green 2000). Finally, the general way choosing between fixed and random effect is a Hausman (1978) test. However, a Hausman test is not to provide which approach is good but just to provide what they are different (Black et al. 2009). In addition, Green (2000) suggests that a Hausman test becomes problematic when use unbalanced panels, as the case in this study.

Thus, this study employs random-effect regression (RE) to test robustness.

Table 3. Random effect estimation results

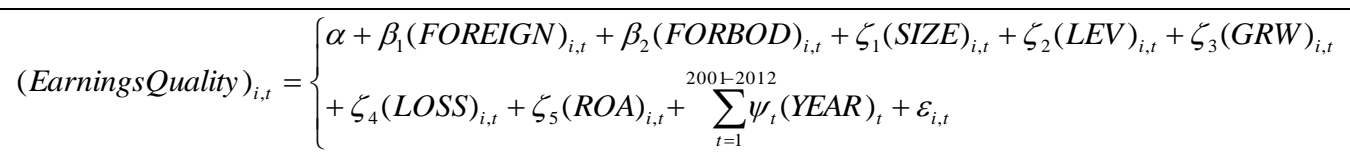

Subscripts $i$ denotes individual firms, $t$ time period. The dependent variable Earnings Quality is four measures of earnings quality: 1) Persistence, 2) Value-Relevance, 3) Conservatism, and 4) Accruals Quality. FOREIGN is the percentage of equity shares held by foreign investors. Foreigner $(F O R)$ is a dummy variable that indicates the presence (one) or absence (zero) of registered foreign citizens on the board.. Firm size $(S I Z E)$ is the natural log of the total assets. Leverage $(L E V)$ is total debt scaled by total assets. Growth prospects $(G R W)$ is market to book ratio of equity. Firm with negative earnings (LOSS) is a dummy variable that takes the value of one if firm's pervious year's net income was negative, and zero otherwise. Profitability $(R O A)$ is return on assets. YEAR is a time dummy.

Superscripts $* * *$, and $* * *$ indicate statistical significance at $10 \%, 5 \%$, and $1 \%$ levels, respectively. $(t$-statistics)

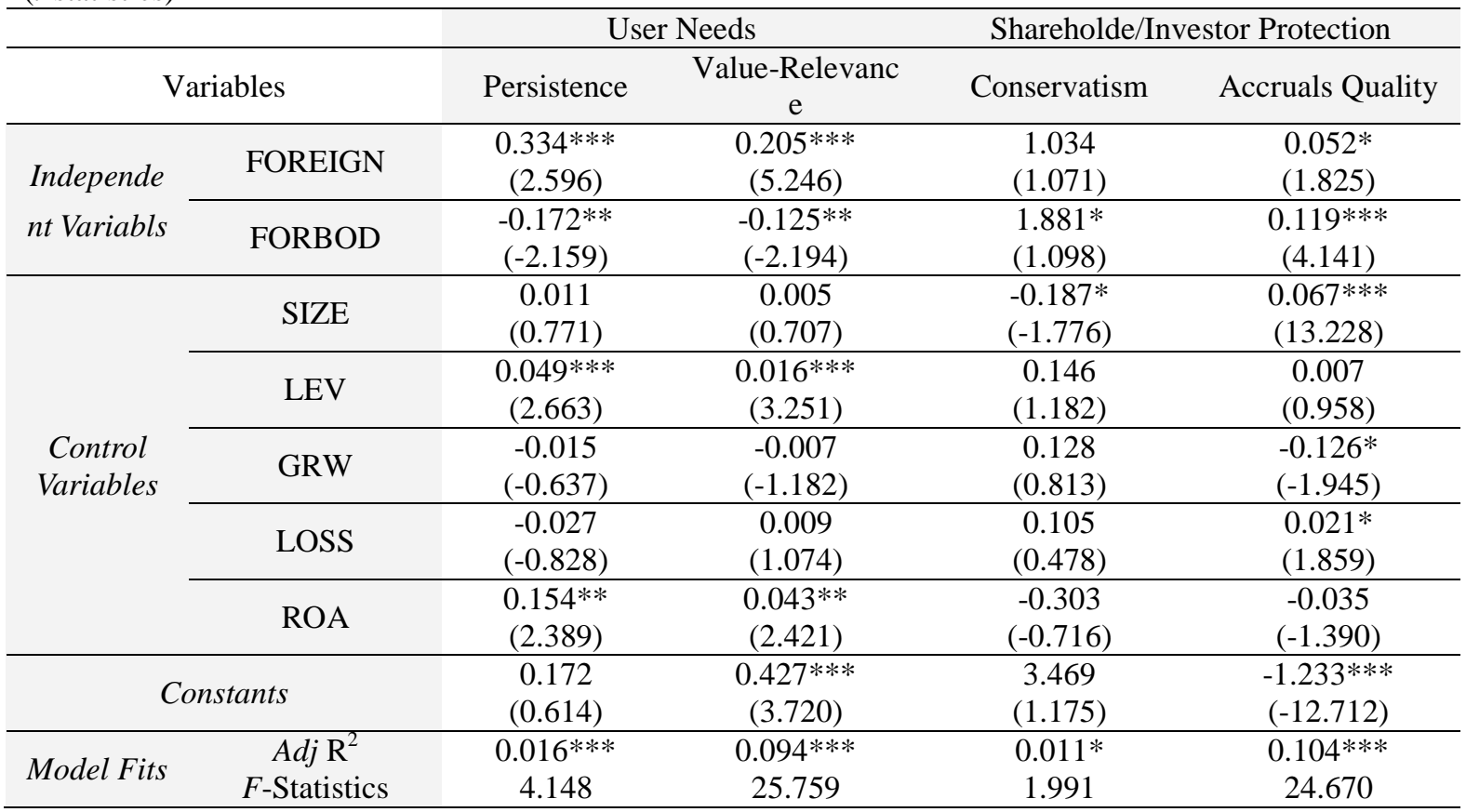

Table 3 represents the GLS random effect estimation. FOREIGN is still significantly positive with both persistence $(0.334, p<0.01)$ and value-relevance $(0.205, p<0.01)$ following the pooled-OLS. In accordance with the result of pooled-OLS, in which FOREIGN has positive sign with accruals quality, the coefficients of FOREIGN on accruals quality is significantly positive (0.052) at 0.10 level in GLS. As discussed in Pooled-OLS, the positive effect of foreign investor on earnings quality $\left(\mathrm{H}_{1}\right)$ should be carefully accepted due to no findings of the positive association with earnings quality on shareholder/investor protection (conservatism and accruals quality). The result of GLS supports this interpretation on foreign investor. The findings of FORBOD on earnings quality remain the same as with the result of pooled-OLS. FORBOD negatively affects earnings quality on user needs: persistence $(-0.172 p$ $<0.05)$ and value-relevance $(-0.125, p<0.05)$. In the association of earnings quality on shareholder/investor protection, 
FORBOD is positive with conservatism $(1.881, p<0.10)$ and with accruals quality $(0.119, p<0.01)$. In contrast to Oxelheim and Randøy's (2003) finding for Swedish firms, foreign investors' participation on the board in Korean firms very limitedly improve earnings quality.

Overall, the major findings of the GLS random effect estimation are consistent with the results of pooled-OLS.

\section{Conclusion}

This study investigates the association between foreign investors and earnings quality. Four key characteristics of earnings quality are identified in two different types of approaches for assessing financial reporting quality: user needs and shareholder/investor protection. The positive impact of foreign investor on earnings quality is evident. Specifically, foreign investor is strongly significant and positively related to earnings quality on user needs perspective (persistence and value-relevance). This result suggests that as institutional investors (outside blockholders), foreign investors play an important role in monitoring management to supplement domestic institutional investor in an emerging market, consistent to Sachs and Warner (1995) and Khanna and Palepu (2000). Accordingly, the active monitoring hypothesis of foreign investors is supported in Korea. However, there is conflicting evidence of foreign investor impacting on earning quality on shareholder/investor protection (conservatism and accruals quality) and the negative effect on accruals quality in GLS. Therefore careful acceptance of active monitoring hypothesis is required. In contrast to the positive impact of foreign investors on earnings quality, foreign outside directors negatively affects earnings quality except for conservatism suggesting their insufficient knowledge of firm and firm's management and perhaps neglects of responsibilities.

In advance, there are two potential limitations related to future research. First, financial reporting quality may differ depending on the legal/judicial regime of foreign investor. Differences between common-law and code-law regimes affect the financial reporting quality and corporate governance system (Ball 2001). Thus, more efforts could also have been made to explain who foreign owners were and from where they came. Second, four proxies of earnings quality in this study do not necessarily reflect all aspects of earnings quality. In this study, the results between foreign investors and earnings quality are mixed, based on the four proxies used. Thus, the results based on the association between corporate governance and earnings quality could depend on how earnings quality is defined.

Overall, this study contributes to the literature providing important evidence that foreign investors as an outside monitor in emerging market affect earnings quality by focusing on the impact on earnings quality exerted by the foreign investors' participation in the board of directors and by major institutional shareholders.

\section{Acknowledgement}

This study was supported by the Tongmyong University Research Grants 2017 (2017A027)

\section{References}

Aggrarwal, R., Erel, I., Ferreira, M., \& Matos, P. (2011). Does governance travel around the world? Evidence from institutional investors. Journal of Financial Economics, 100(1), 154-181. https://doi.org/10.1016/j.jfineco.2010.10.018

Bae, K., Ozoguz, A., Tan, H., \& Wirjanto, T. S. (2012). Doe foreigners facilitate information transmission in emerging markets?. Journal of Financial Economics, 105(1), 209-227. https://doi.org/10.1016/j.jfineco.2012.01.001

Ball, R., \& Shivakumar, L. (2005). Earnings quality in U.K. private firms; Comparative loss recognition. Journal of Accounting and Economics, 38, 83-128. https://doi.org/10.1016/j.jacceco.2004.04.001

Ball, R., Kothari, S. P., \& Robin, A. (2000). The effect of international institutional factors on properties of accounting earnings. Journal of Accounting and Economics, 29(1), 1-51. https://doi.org/10.1016/S0165-4101(00)00012-4

Ball, R., Robin, A., \& Wu, J. S. (2003). Incentives versus standards: properties of accounting income in four East Asian countries. Journal of Accounting and Economics, 36(1), 235-270. https://doi.org/10.1016/j.jacceco.2003.10.003

Balsam, S., Krishnan, J., \& Yang, J. S. (2003). Auditor industry specialization and earnings quality. Auditing: A Journal of Practice and Theory, 22, 71-97. https://doi.org/10.2308/aud.2003.22.2.71

Baltagi, B. (2005). Econometric analysis of panel data. John Wiley \& Sons.

Choe, H., Koh, B-C., \& Stulz, R. M. (2005). Do domestic investors have an edge? The trading experience of foreign investors in Korea. Review of Financial Studies, 18, 795-829. https://doi.org/10.1093/rfs/hhi028 
Choi, H., Sul, W., \& Cho, Y. (2011). Board structure, minority shareholders protection, and foreign block ownership. The Journal of Professional Management, 14(2), 1-26.

Choi, J-S. (2007). Changes in the forecast relevancy, persistence, and valuation relevancy of earnings components between before and after the Financial Crisis. Accounting and Auditing Research, 45, 237-276. [Printed in Korean]

Dechow, P., \& Dichev, D. (2002). The quality of accruals and earnings: the role of accrual estimation errors. The Accounting Review, 77, 35-59. https://doi.org/10.2308/accr.2002.77.s-1.35

Dhalquist, M., \& Robertsoon, G. (2001). Direct foreign ownership, institutional investors, and firm characteristics. Journal of Financial Economics, 59, 413-440. https://doi.org/10.1016/S0304-405X(00)00092-1

Fransis, J., LaFond, R., Olsson, P. M., \& Schipper, K. (2004). Costs of equity and earnings attributes. The Accounting Review, 79, 967-1010. https://doi.org/10.2308/accr.2004.79.4.967

Graves, S. B. (1988). Institutional ownership and corporate R\&D in the computer industry. Academy of Management Journal, 31(2), 417-428. https://doi.org/10.5465/256557

Grinblatt, M., \& Keloharju, M. (2000). The investment behavior and performance of various investor types: a study of Finland's unique data set. Journal of Financial Economics, 55, 43-67. https://doi.org/10.1016/S0304-405X(99)00044-6

He, W., \& Shen, J. (2014). Do foreign investors improve informational efficiency of stock prices? Evidence from Japan. Pacific-Basin Finance Journal, 27, 32-48. https://doi.org/10.1016/j.pacfin.2014.01.005

Himmelberg, C. P., Hubbard, R. G., \& Palia, D. (1999). Understanding the determinants of managerial ownership and the link between ownership and performance. Journal of Financial Economics, 53(3), 353-384. https://doi.org/10.1016/S0304-405X(99)00025-2

Huang, W., \& Zhu, T. (2015). Foreign institutional investors and corporate governance in emerging markets: Evidence of a spilt-share structure reform in China. Journal of Corporate Finance, 32, 312-326. https://doi.org/10.1016/j.jcorpfin.2014.10.013

Jonas, G. J., \& Blanchet, J. (2000). Assessing quality of financial reporting, Accounting Horizons, 14(3), $353-363$. https://doi.org/10.2308/acch.2000.14.3.353

Kang, J. K., \& Stulz, R. M. (1997). Why is there a home bias? An analysis of foreign portfolio equity ownership in Japan. Journal of Financial Economics, 46, 3-28. https://doi.org/10.1016/S0304-405X(97)00023-8

Khanna, T., \& Palepu, K. G. (2000). Is group affiliation profitable in emerging markets: An analysis of diversified Indian business groups. Journal of Finance, 55, 867-891. https://doi.org/10.1111/0022-1082.00229

Kim, J. B., Krinsky, I., \& Lee, J. (1997). Institutional holdings and trading volume reactions to quarterly earnings announcements. Journal of Accounting, Auditing \& Finance, 12(1), 1-14. https://doi.org/10.1177/0148558X9701200101

Lev, B. (1989). On the usefulness of earnings and earnings research: Lessons and directions from two decades of empirical research. Journal of Accounting Research, 153-192. https://doi.org/10.2307/2491070

Lien, D., Tseng, M. C., \& Wu, S. (2013). Foreign investors in Taiwan: Their roles and government perspectives. Business Horizons, 56, 749-756. https://doi.org/10.1016/j.bushor.2013.07.007

Oxelheim, L., \& Randøy, T. (2003). The impact of foreign board membership on firm value. Journal of Banking and Finance, 27, 2369-2392. https://doi.org/10.1016/S0378-4266(02)00395-3

Sachs, J., \& Warner, A. (1995). Economic reform and the process of global integration. Bookings Papers on Economic Activity, $25^{\text {th }}$ Anniversary Issue. https://doi.org/10.2307/2534573

Schipper, K., \& Vincent, L. (2003). Earnings quality. Accounting Horizons, 17, 97-110. https://doi.org/10.2308/acch.2003.17.s-1.97

Watts, R. L., \& Zimmerman, J. L. (1990). Positive accounting theory: A ten-year perspective. The Accounting Review, 65(1), 131-158.

Wooldridge, J. M. (2002). Econometric analysis of cross-section and panel data. Cambridge, Massachusetts; London: MIT Press.

Zhou, X. (2001). Understanding the determinants of managerial ownership and the link between ownership and performance: comment. Journal of Financial Economics, 62, 559-571. https://doi.org/10.1016/S0304-405X(01)00085-X 